\title{
The 1972 Soviet-American Youth Conference: The Illusion of Consensus
}

\section{Andrew Jacobs}

\section{Introduction}

Hoping to capitalize on the spirit of détente, in June 1972 the National Council of American-Soviet Friendship (hereafter the NCASF, the official Soviet-American friendship group headquartered in Manhattan) and the Soviet Committee of Youth Organizations (hereafter the KMO, the umbrella organization administering the various Soviet youth groups) co-sponsored the first-ever Soviet-American Youth Conference held in Minsk. The conference proposed to feature around 100 young people from each side discussing issues relevant to youth the world over"their hopes and problems and participation in the social struggle," university life, future careers, war and peace, racism, imperialism, and national liberation. ${ }^{1}$ The topics, particularly the attention devoted to peace and imperialism, revealed the pro-Soviet orientation of the NCASF and hinted the conference would feature much discussion of the Soviet Union's pet causes. Still, the NCASF and the KMO promised to field diverse delegations and facilitate open dialogue. ${ }^{2}$ The sponsors of the conference envisioned the event as an attempt to bridge the Cold War divide, make friends, and generate solidarity across borders. Frank discussion at the conference would build mutual understanding and serve as an example of future possible dialogue between two sides now eager and able to get to know one another.

This article examines the 1972 Soviet-American Conference as a transnational point of interaction between the Soviet Union and the United States, wherein youth from both sides exchanged experiences, ideas, and representations of them-

*I extend thanks to Anne Klejment, Hiroaki Kuromiya, and Padraic Kenney who read earlier versions of this article and an audience at the Midwest Russian History Workshop which read a draft. My thanks also to the journal's anonymous reviewer for their helpful suggestions.

1 NCASF Press Release about the conference, June 17, 1972, Rossiiskii gosudarstvennyi sotsial'no-politicheskii arkhiv (RGASPI) f. M-3, op. 8, d. 299, 11. 1-2. For the proposed discussion topics, see RGASPI, M-3, op. 8, d. 299, 11. 3-5. See also the NCASF recruiting advertisement for the conference, National Archives, College Park, Maryland (NARA) RG 59, A1-5345, Box 19.

2 NCASF Press Release, RGASPI f. M-3, op. 8, d. 299, 11. 1-2; "US-USSR Young People's Conference: A Preliminary Report," New World Review, Summer 1972, 16. 
selves. Things did not go as planned however. As we will see, the Soviet effort to control all aspects of the conference, including the composition of the American delegation, inadvertently led to stereotypes being confirmed rather than rejected. Because of the make-up of each delegation, the conference produced an ultimately distorted but seemingly clichéd image of both sides in which Soviet youth appeared as a monolithic bloc of devoted patriots and the Americans as alienated youth. Much of this divergence related to differing perspectives on the importance of national consensus. For the Komsomol members (the youth wing of the Communist Party) who made up the Soviet delegation and who acted as the official representatives of Soviet youth, national consensus remained an absolute virtue. By 1972, with the Vietnam War still raging and the memory of the turmoil of the 1960s still lingering, many of the American youth at the conference by contrast rejected any display of national consensus. This gap in life experience and perspective made solidarity, the ultimate goal of the conference, difficult to generate.

\section{Détente, Cultural Exchange, and Youth}

The 1972 Youth Conference occurred during the high-point of détente and post-war American-Soviet cooperation. The Nixon-Brezhnev Summit occurred only a month prior in Moscow which included the signing of the SALT I agreement and the Anti-Ballistic Missile Treaty. Détente (c. 1969-1977), a period of improved relations between the USSR and the US, developed generally on two tracks. One track featured high-level summits, such as the Nixon-Brezhnev meetings, along with official exchanges in the fields of science, technology, and culture. Another track featured American non-governmental organizations along with individuals seeking out contact with the Soviet Union and vice versa in the hope of improving relations and mutual understanding under the cover of détente. Such contact flourished during this period and would continue unabated even after this era in the Cold War passed.

To trust each other, they needed to get to know one another first believed many of these Americans. Because no "grassroots" groups existed in the Soviet Union, all the American groups and individuals desiring contact had to work through Soviet government organizations to establish contact with the Soviet public, including at the 1972 Youth Conference. The Soviet government and its various organizations, serving as gatekeepers for the Soviet public, thus held the upper-hand in this relationship and the USSR used this power differential to secure formats, conditions, and delegations more favorable to its position. This feature of American-Soviet engagement would have a major impact on how the 1972 Youth Conference unfolded.

In recent years, historians have begun to examine closely citizen-level exchange within and between the various blocs during the Cold War. Many of these new histories center their narratives on how average citizens sought to navigate and ultimately transcend the Cold War divide and seek out peaceful solutions to the pressing international problems of their day. As a result, these new histories by focusing on the transnational connections, networks and transfers of knowledge, ideas and cultural products across borders during the Cold War have problematized 
concepts such as separate blocs and the "Iron Curtain."3 This chapter provides a microhistory of this kind of cultural exchange between the two systems which offered the opportunity for people from both sides to better understand each other.

The conference also occurred amid a worldwide youth rebellion. The conference allowed each side to showcase their youth and the opportunity to understand the other's young people. On both sides of the Cold War divide, the rebellious status of youth and a yawning generation gap generated much interest and concern. Dissatisfied by the stasis of the day and dismayed by the war in Vietnam that alienated them from their government, some American youth in the 1960s rebelled at home, on their college campuses, and in the streets. Many participated in a global counterculture that tried to overturn the gender, racial, political, and sexual norms of the previous generation. ${ }^{4}$ Dissent and rebellion had likewise taken root among some Soviet youth during the 1960s and 1970s. Soviet leaders worried about their inability to mobilize a seemingly apathetic or rebellious younger generation disappointed with the rigidity of the Party and its broken economic promises. Soviet authorities additionally fretted over what they considered the corrosive impact western popular culture, ideas, and ways of life pouring over Soviet borders had on their young people. ${ }^{5}$ In a more extreme instance and in an example of growing

3 See for example, Sari Autio-Sarasmo and Katalin Miklossy, eds., Reassessing Cold War Europe (London: Routledge, 2011); Patryk Babiracki and Kenyon Zimmer, eds., Cold War Crossings: International Travel and Exchanged across the Soviet Bloc, 1940s-1960s (College Station, TX: A\&M University Press, 2014); Pia Koivunen and Simo Mikkonen, eds., Beyond the Divide: Entangled Histories of Cold War Europe (New York: Breghahn Books, 2015); Patryk Babiracki and Austin Jersild, eds., Socialist Internationalism in the Cold War: Exploring the Second World (Cham, Switzerland: Palgrave MacMillan, 2016); Peter Romijn, Giles Scott-Smith and Joss Segal, eds., Divided Dreamworlds?: The Cultural Cold War in East and West (Amsterdam: Amsterdam University Press, 2012). For other works focusing on government-sponsored cultural exchange see, Yale Richmond, Cultural Exchange, and the Cold War: Raising the Iron Curtain (University Park: Penn State University Press, 2003); Walter Hixon, Parting the Iron Curtain: Propaganda, Culture, and the Cold War, 1945-1961 (New York: St. Martin's Press, 2007); Penny Von Eschen, Satchmo Blows Up the World: Jazz Ambassadors Play the Cold War (Cambridge, MA: Harvard University Press, 2004); Kiril Tomoff, Virtuosi Abroad: Soviet Music and Imperial Competition During the Early Cold War, 1945-1958 (Ithaca, NY: Cornell University Press, 2015).

4 Todd Gitlin, The Sixties: Years of Hope, Days of Rage (New York: Bantam Books, 1987); Paul Berman, A Tale of Two Utopias: The Political Journey of the Generation of 1968 (New York: W.W. North \& Co. 1996); Howard Brick and Christopher Phelps, Radicals in America: The US Left Since the Second World War (Cambridge University Press, 2015).

5 On post-Stalin Soviet youth and rebellion, see and Aleksei G. Borzenkov, Molodezh'i politika: Vozmozhnosti i predely studencheskoi samodeiatel'nosti na vostoke Rossii (1961-1991 gg.) (Novosibirsk, 2003); Robert Hornsby, Protest, Reform, and Repression in Khrushchev's Soviet Union (Cambridge: Cambridge University Press, 2013), 68-71, 81-7, 102-7; Sergei Zhuk, Rock and roll in the Rocket City: the West, identity, and ideology in Soviet Dnepropetrovsk, 1960-1985 (Baltimore: Johns Hopkins University Press, 2010); Alexei Yurchak, Everything Was Forever Until It Was No More: The Last Soviet Generation (Princeton: Princeton University Press, 2005); Allen Kassof, "Youth 
nationalist dissent, less than two months before the conference Romas Kalanta, a 19-year old student from Lithuania, burned himself to death to protest Soviet rule in Lithuania. Following Kalanta's funeral, a mass demonstration occurred with crowds calling for "freedom for Lithuania," "freedom for youth" and "freedom for hippies." None of these aspects of Soviet youth rebellion would appear among the Soviet delegation to conference, but features of the American youth rebellion would figure prominently among the American delegates.

What made this event unique in the history of Soviet-American cultural exchange is that it existed outside the formal network of government-sponsored Cold War exchange. The US government did not sponsor, fund, vet, or endorse the American delegation or the conference. ${ }^{7}$ The American delegates in turn did not seek to act as representatives of their home country. Indeed, as we will see, many of the Americans in Minsk used this alternative form of cultural exchange to present a harsh and unforgiving picture of America with the conference showcasing the breakdown of the American Cold War consensus. On the other hand, the Soviet delegation was closely vetted by the state and presented the opposite: a glorious picture of the Soviet Union and a model of national consensus.

\section{The Conference}

The five-day conference, which featured a series of speeches and discussion sessions in a hotel conference room in Minsk in the Belarussian Republic, offered a rare opportunity for American youth eager to see the Soviet Union for themselves. During their time in the Soviet Union, the Americans would also visit Leningrad and Moscow and partake in group excursions to key sites in Belarus, especially those related to World War II. ${ }^{8}$ While a few thousand young Americans had visited the USSR since the country's re-opening in 1956, this conference promised what many Americans hoping to visit the Soviet Union were most eager

vs. the Regime," Problems of Communism, 6 (May-June 1957), 15-21; Vlasislav Zubok, Zhivago's Children: The Last Russian Intelligentsia, (Cambridge: Harvard University Press, 2011); William Taubman, The View from Lenin Hills: Russian Youth in Ferment (New York: Coward McCann, 1967), 239-48.

6 Amanda Jeanne Swain, "From the Big Screen to the Streets of Kaunas: Youth Cultural Practices and Communist Party Discourse in Soviet Lithuania," Cahiers $d u$ Monde Russe 54:3/4 2013, 468.

7 Although the US government played no role in the conference, it did monitor the proceedings and paid close attention to the backgrounds of the American delegates. Memo from Charles Stefan to Mr. Armitage on American-Soviet Young People's ConferenceAugust 19 to September 5, 1973, August 10, 1973, National Archives, College Park, MD (NARA), RG 59, A1-5345 Box 32. This continued into the 1980s. See FBI file on the American-Soviet Youth Forum, FOIA request 1392030-0, in author's possession.

8 Initial promises of sporting activities and other competitions did not seem to materialize however. Richard Morford (executive director of the NCASF) letter to Nesterov, April 20, 1972, RGASPI f. M-3, op. 8, d. 435, 11. 112-5. Long sessions of Komsomol dancing and other musical performances apparently did occur, however. These cultural performances would become more important at later conferences during which the American side also performed. One participant at the 1974 conference in Baku remembered playing Fauré on her flute. Interview with Sally Pratt, February 20, 2018. 
for: the chance to meet with Soviets of their generation on Soviet turf and to see if they truly were "just like us." From the many letters written by young Americans to Soviet officials, many found the Soviet Union fascinating and dreamed of the chance to visit the USSR to meet and live among Soviets their own age. ${ }^{10}$ The American participants were therefore willing to sit through the conference's lengthy plenary sessions featuring dry reports if such speeches would be followed by small group discussions.

The conference quickly proved challenging and things occasionally got weird. The two sides approached the conference differently. Even as the Soviet organizers gestured towards dialogue, the Soviet side approached the conference didactically. They would use the conference as an opportunity teach their ignorant Americans guests about their country, make them aware of Soviet achievements, and inform them about the devotion of their nation's youth to the country's future success. The conference offered a "huge potential possibility" for influencing American youth ideologically, noted one Soviet report. ${ }^{11}$ Places visited by the American delegation supplemented what they were taught during the conference's formal sessions. "They put us through a real learning process," complained one American attendee. "First they told us what we would see, then they reinforced it by showing, and they reinforced it again by talking about it." 12 For example, Soviet presentations not only extolled the peace proposals of the Soviet government, the hosts also shepherded their guests to sites related to World War II (the memorial at Khatyn which commemorated a Belarussian village decimated by the Nazis, for example). There the Americans learned not only of the great suffering endured by the Soviet population during World War II which served to confirm the USSR's authentic present commitment to peace but also to illustrate the great strides the country made to recover from the devastation wrought by the Nazi invasion. ${ }^{13}$

9 Some young Americans had attended previous international summits, conferences and festivals held in the USSR. A total of 150 "North Americans" (Americans + Canadians) attended the massive (33,000 total attendees) 1957 World Festival of Youth and Students in Moscow. Smaller numbers had participated in various student and peace meetings in the USSR. Pia Koivunen, 'Friends, 'Potential Friends,' and Enemies: Reimagining Soviet Relations to the First, Second and Third Worlds at the Moscow 1957 Youth Festival," in Socialist Internationalism in the Cold War: Exploring the Second World, ed. Patryk Babiracki and Austin Jersild (Cham, Switzerland: Palgrave MacMillan, 2016), 225.

${ }^{10}$ For example, Letter from T. Dutton to "whoever reads this letter," 1965, RGASPI, f. M-5, op. 1, d. 395, 11. 114-9.

${ }^{11}$ Report about the meeting of Soviet and American youth, RGASPI f. M-3, op. 8, d. $299,1.112$. The Komsomol played an important role in working with foreign youth and the effort to win them over, see Robert Hornsby, "The post-Stalin Komsomol and the Soviet fight for Third World youth, ” Cold War History, 16, no. 1, 2016, 83-100.

12 "U.S Maoist Youth Finds Soviet a Doctrinaire Place," New York Times, July 11, 1972.

${ }^{13}$ The KMO most likely chose Belarus as the site of the conference because it had been the site of so much devastation during the war. The Americans also laid flowers at war memorials and cemeteries in Moscow and Leningrad at this conference. 


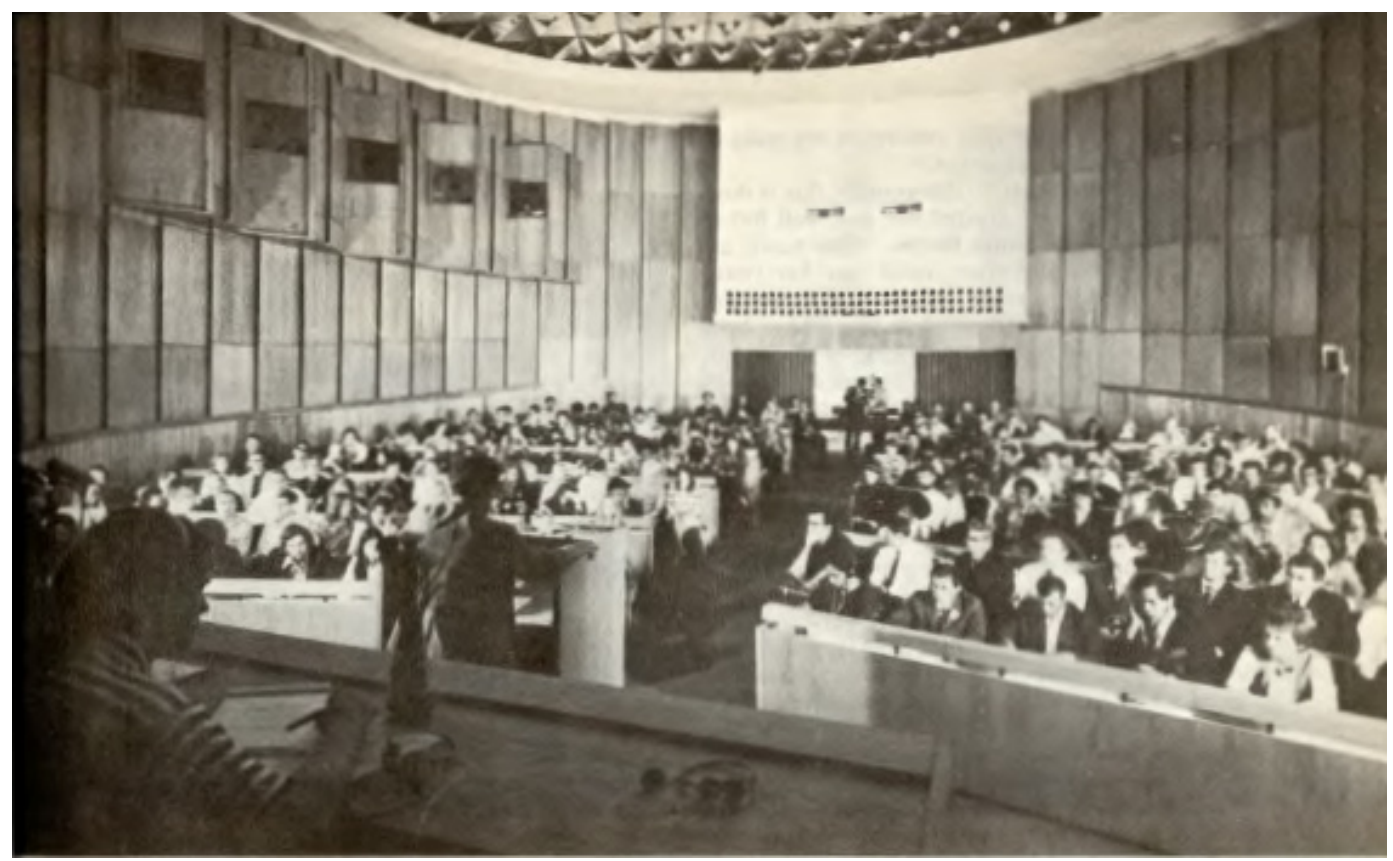

Plenary Session at the 1974 Soviet-American Youth Conference in Baku, from Their Point of View: Young Americans in the USSR, Moscow: Progress Publishers, 1977.

Many of the Americans, by contrast, took the conference as an opportunity to explore a foreign country, to have fun, and socialize with a group of people they had only read or heard stories about. The Soviet side, made up of Party and Komsomol members, saw the conference as an extension of their Party work. ${ }^{14}$ Their formal and carefully prepared presentations and the tightly organized structure of the conference came off poorly at times. "Cold and dry, and definitely too long," according to one American. ${ }^{16}$ Spontaneity was never the name of the game at Soviet-hosted or sponsored conferences. The Komsomol ran a tight ship at such events with "boring, pro-forma speeches" dominating the agendas, even at events held beyond Soviet borders such as the 1968 World Youth Festival in Sofia. Objections, deviations, and protests were frowned upon and shut down. ${ }^{17}$

${ }^{14}$ In the comments of American participants collected by KMO, a few Americans said they wished the American side had taken the conference more seriously and had better prepared for the event and discussions. Other than the Young Workers Liberation League contingent, none of the Americans appeared to participate in any preparatory activities. See the comments from James Steele and Ed Rivera, RGASPI f. M-3, op. 8, d. 575, 11. 57-64.

${ }^{15}$ While I found no information about the specific preparations for the 1972 conference other than a call for more preparation, for the 1973 conference in the US, the Soviet delegation underwent training and attended various preparatory events, see RGASPI f. M-3, op. 8, d. 575, 11. 16-18, 32-5.

${ }^{16}$ Comment from Earl Scott in "US-USSR Youth Conference, Minsk, 1972", New World Review, Winter 1973, 41.

${ }^{17}$ See Nick Rutter, "Look Left, Drive Right: Internationalisms at the 1968 World Youth Festival," in The Socialist Sixties, ed., Anne Gorsuch and Diane Koenker (Bloomington, IN: Indiana University Press, 2013), 201-3. The Youth Festivals held in the neutral countries of Austria (1959) and Finland (1961) proved much more problematic. At these festivals, the CIA with the help of the American delegation launched covert propaganda campaigns 
Some KMO reports found faults in the organization of the 1972 conference. The overly substantive and informational nature of the Soviet presentations, according to a Soviet participant, reduced their intended propagandistic impact on the Americans by boring them. According to participants at later conferences the presentations remained dull. ${ }^{18}$ In Minsk and the subsequent conferences, the Americans at times felt like they were not listening to Soviet youth express their own personal thoughts but instead hearing reports by Soviet academic specialists on the youth problem. To keep the attention of the Americans, the presentations in the future should be reduced to simply busting bourgeoisie propaganda and destroying stereotypes, not dumping an "avalanche" of detailed information on them as happened at the 1972 conference. The Americans, a very lively and perhaps frivolous bunch per Soviet reports, expected more free-flowing, informal discussions and relished the chance to meet with Soviet youth on Soviet streets, not being lectured to by Soviet officials in conference rooms. ${ }^{19}$ One American delegate remembered that the Soviet side loaded their presentations with statistics and were frequently irritated by the presentation style of the Americans, which he described as "ill-informed bull shitting." ${ }^{20}$ At future conferences, a report from one Soviet participant suggested the plenary sessions be curtailed in favor of more discussion, free time, and a cultural program. These meetings needed to have a less "official" and "tense" character in the future. Yet, the Soviet participants still needed more training and preparation according to the KMO. ${ }^{21}$

Overall, relations between the delegations developed in a friendly manner. In the comments collected by the KMO and in a subsequent book and articles published in Soviet Life about the conference, the Americans effusively praised the country and noted their appreciation for being allowed to see the Soviet Union's remarkable achievements with their own eyes. ${ }^{22}$ Even though the American delegation reportedly possessed a special talent for polemicizing, the Soviet side was spared having to answer provocative questions, according to KMO reports. ${ }^{23}$ Indeed, the Soviet side struggled with only a few topics. A "hot debate" occurred on the position of women. The American side argued gender inequality had to be

meant to delegitimize the festivals and attack the USSR. The American delegations at these festivals had a stronger anti-communist bent and were better prepared. All future Youth Festivals would be held in Soviet-allied countries. Joni Krekola and Simo Mikkonen, "Backlash of the Free World: The US presence at the World Youth Festival in Helsinki, 1962," Scandinavian Journal of History 36, 2 (2011), 230-255.

${ }^{18}$ Interview with Sally Pratt, February 20, 2018.

19 "Report about the meeting of Soviet and American Youth," RGASPI, M-3, op. 8, d. $575,11.112-124$.

${ }^{20}$ Lars Lih, "Account of a Trip to the Soviet Union in the 1970s" (unpublished). I thank Lih for providing this to me.

21 "Report about the meeting of Soviet and American Youth," RGASPI, M-3, op. 8, d. $575,11.112-124$.

${ }^{22}$ The praise for the country was nearly universal. However, the conferences themselves are hardly discussed, see Maya Gordeyeva, Their Point of View: Young Americans in the USSR, (Moscow: Progress Publishers, 1977).

23 "Report about discussion group Y," RGASPI f. M-3, op. 8, d. 299, 11. 108-111; “Report on Working Group III," RGASPI, M-3, op. 8, d. 299, 11. 70-2. 
attacked on economic, political, and social grounds including the rooting out of male chauvinism. The Soviet delegates, some of the Americans complained, as good Communists could only see the issue in terms of economics. ${ }^{24}$ When a few of the American women edged the conversation towards more intimate matters, including sexual intercourse, the "Soviets couldn't handle it; in their culture, they just aren't ready to discuss these things publicly," according to the American report of the conference..$^{25}$ The touchy subject of women's liberation would remain a controversial topic for similar reasons at several of the later conferences. ${ }^{26}$

\section{The Soviet Delegation}

The most obvious difference between the delegations was the age of the Soviet participants. As soon became apparent to the Americans, Soviet and American conceptions and definitions of youth clashed. The American side at this Youth Conference consisted mostly of college students and young people in their early 20 s. The Soviet contingent, on the other hand, included many people in their thirties and even older. The Soviet Union defined youth in broader terms, anyone under 30. The Komsomol included individuals up to age 28. This generous definition of youth allowed KMO officials to include several professionals along with senior Komsomol members in the conference and therefore stack the conference with the kinds ultra-prepared and trustworthy young people who were the only types allowed to represent the Soviet Union at such events. ${ }^{27}$ A KMO report noted several of the Americans criticized this age gap. "Why are the majority of the presenters at the plenary sessions people who are not youths, even though this is a youth conference?" asked one American. Next year, the KMO report suggested the conference include fewer "venerable scientists" and more students. ${ }^{28}$ In the past, American tourist officials had complained that Soviet delegations to the US intended for students and other young people too often included participants much older than they should have been. ${ }^{29}$ Indeed, some of the first Soviet youth

24 "Report about discussion group Y," RGASPI f. M-3, op. 8, d. 299, 11. 108-111.

25 "US-USSR Youth Conference," 53.

${ }^{26}$ Sally Pratt and Sharon Carnicke, "USA-USSR Youth Meet, 1973," New World Review, March-April 1974. Holman, the chief American organizer, noted that some Americans at the 1979 conference in Atlanta complained that the Soviet delegation included too few women. He wrote: "Many Americans both acquainted and unacquainted with the Soviet Union, are yet to be convinced of truly equal status for women there." Sending more women would alleviate this misconception, wrote the American. Holman letter to Gennady Yanaev, December 10, 1979, RGASPI f. M-3, op. 9, d. 1245, 11. 17-21.

${ }^{27}$ For a list of Soviet participants at the meeting, see RGASPI f. M-3, op. 8, d. 299, 11. 8-15, 16-19. Two American attendees estimated the average of the Soviet delegation to be early 30s. "U.S Maoist Youth Finds Soviet a Doctrinaire Place," New York Times, July 11, 1972.

${ }^{28}$ Report about the meeting of Soviet and American Youth, RGASPI f. M-3, op. 8, d. 575, 11. 112-124.

${ }^{29}$ Record of a conversation between KMO and the Council for Student Travel, RGASPI f. M-5, op. 1, d. 76, 11. 88-92. 
admitted to the US as part of one the earliest youth exchanges in the post-Stalin period included individuals forty years of age and older. ${ }^{30}$

The KMO's tendency to load such conferences and delegations with trusted individuals (and for youth events this meant Komsomolites) became problematic again the following year at the second conference held in the United States. The American organizers of the conference complained of difficulty in securing visas for the Soviet delegation because the KMO attempted to fill all their slots with Komsomol and Communist Party members. " "Perhaps, some of these people should not be members of either [the] Communist Party or the Komsomol," kindly suggested John Holman, the American organizer of the conference and participant in the 1972 edition. ${ }^{32}$ This request went unheeded; the KMO sent a near-full slate of Party and Komsomol members and would do so at the future Soviet-American Youth Conferences.

The peculiar nature of the Soviet delegations would be noted at the future Youth Conferences. An American newspaper covering the 1973 conference in the US described the visiting Soviets as "professional delegates in their mid-30s" with a "token Jew" thrown in to assuage concerns over Soviet anti-Semitism. ${ }^{33}$ An American who worked as an interpreter at the 1973 and 1974 conferences remembered most of all the major "mismatch" between the American and Soviet delegations. The Soviet delegation appeared to consist of individuals already in "established careers," including engineers, published writers, and performing artists, which contrasted mightily with the American college students. Such a mismatch resulted in a lost opportunity. "I wonder how the experience would have been different if we had met kids [like us] or if they had met American professionals," recalled one participant. ${ }^{34}$

\section{The Appearance of Consensus}

During the Cold War, the United States and the Soviet Union strived for the appearance of national consensus and unity. Throughout the Cold War, both sides

30 "Memorandum of Discussion at the $242^{\text {nd }}$ Meeting of the National Security Council," Washington, March 24, 1955, Foreign Relations of the United States, 19551957, Soviet Union, Eastern Mediterranean, Volume XXIV.

${ }^{31}$ Party members needed a special waiver from the State Department to enter the US.

${ }^{32}$ Holman "personally [however] had no strong reservations about the composition of the delegation." John Holman letter to the KMO, RGASPI f. M-3, op. 8. d. 691, 11. 12-3.

${ }^{33}$ Roster for the conference, RGASPI f. M-3, op. 8, d. 575, 11. 22-5; Clipping from the American newspaper, Jewish Journal, RGASPI f. M-3, op. 8. d. 691, 1. 224. The profile of these delegates matched those of Soviet citizens allowed to travel abroad to the capitalist west. Those tourists were usually from elite professions who had to undergo a significant amount of vetting before departure. Anne Gorsuch, All This is Your World: A History of Soviet Tourism at Home and Abroad after Stalin (University of Oxford Press, 2011), 110-1.

${ }^{34}$ Author's correspondence with Sharon Carnicke, December 20, 2017. By 1975, the two sides were still debating the appropriate age of the conference's participants as well as the purpose of the event. John Holman letter to Pilipov, September 29, 1975, RGASPI f. M-3, op. 8, d. 1263, 11. 37-8. The continuing age discrepancy was also recalled by another participant. Interview with Sally Pratt, February 20, 2018. 
sought to establish a united front to stand tall in the face of a foreign danger threatening to topple their way of life - the Red Menace or alternatively Capitalist Encirclement - and to project strength to the outside world. The appearance of popular consensus and national unity additionally provided legitimacy for the state and its leadership and suggested a happy population satisfied by their country's economic and social model.

The presence of Party members and Komsomolites at the conference, above all, offered the prized appearance of consensus among Soviet youth. Societal harmony was an important aspect of Soviet identity and Soviet authorities sought to project this image to visitors. At Soviet-sponsored Youth Festivals, peace meetings, and other international events mounted with great regularity during the Cold War, the Soviet delegations strived to form a united front together with the other participating delegations from around the world in opposition to American imperialism. When prominent Americans paid a visit, the appearance of consensus among Soviet youth was often highlighted. Samantha Smith's visit to the USSR a decade later to verify the USSR's commitment to peace served as an opportunity for the Soviet Union to showcase a united front of patriotic Soviet youth. During her visit to the Young Pioneer Camp Artek and before a bank of international television cameras and journalists, happy Soviet youth stood in unison in favor of their government's peace campaign, sang patriotic songs, and smiled while serving as the welcoming hosts to an important government guest.

At this conference, the Soviet presentations came across as performances of patriotism with many of them seeking to sell to a foreign audience all the Soviet Union offered its young people. The young Soviet participants stressed their collective unity, championed the benefits of being Soviet, including good pay, job security along with the right to work, education, and relaxation, and declared their loyalty to their country and their pride in it. And they owed it all to the state. ${ }^{35}$ Finally, they asked their American guests to join them in seeking peace and opposing imperialism. Their speeches emphasized their unity. The Soviet presenters confidently spoke not for themselves as individuals, but rather from the perspective of all Soviet youth — we, not I and our, not my are used throughout — with the delegation of 100 taking the shape of a monolithic bloc. "Soviet youth have no interests and aims that differ from the interests and aims of the Soviet people," declared one report furthering conjuring up the image a monolith that clashed with the diversity of the American delegation. ${ }^{36}$

What did the individual Soviet participants make of the conference and the presentations they delivered? Were they as patriotic and loyal to their country as they claimed? In the past when commentators attempted to understand the motivations of Soviet youth, especially those of the Komsomol, they chalked up their

35 "Soviet Youth: Its Role and Place in Society," presentation by Baglai and Danilenko, RGASPI, M-3, op. 8, d. 299, 11. 45-55. See also the American description of the Soviet presentations in an NCASF published pamphlet of the conference in Tamiment Library and Robert F. Wagner Labor Archives, New York University, TAM 134, Box 7, Folder 92.

${ }^{36}$ Presentation (author unlisted) "Youth in Soviet Society" in "US-USSR Youth Conference," 66-68. 
support for the Soviet state and the Communist Party as either the result of forced indoctrination and coercion or a consequence of their attempt to get ahead in life and move up the Soviet social, economic or political ladders.

The archives contain little insight into how the individual Soviet participants viewed this conference. ${ }^{37}$ Alexei Yurchak, however, has offered an alternative route to understanding the behavior of Soviet youth and the public at large. For Yurchak, Komsomolites of this time (what he calls "late socialism") found pleasure in declaring their loyalty to their Party and their country because it offered them a shared sense of unity and solidarity with a dominant, official discourse guiding their actions. ${ }^{38}$ Yet also by the 1970 s due to the dominance of this official discourse many acts considered political, such as the speeches given at this conference, became ritualized, "hypernormalized" or performative to the point where participating in them became more important than what was said. Whether it was an editorial in Pravda, a speech from a Party official, or the Komsomol presentations here, official speech of all kinds became devoid of any real meaning. The "Soviet authoritative language" deployed by the Komsomol at this conference then only mimicked actual political debate because the language used by the Komsomolites here and elsewhere had long since been scripted and took on a static, ritualized form replicated everywhere. ${ }^{39}$ Even, here in front of a foreign audience where one might think more creativity would be necessary, these Komsomolites apparently still produced the authoritative discourse. At future SovietAmerican Youth Conferences, the Soviet delegations continued to sing a song of total harmony. At the 1981 conference, for example, the Soviet delegation shared with their American guests that "It can be said with absolute certainty that practically every Soviet person [and] all the young people of our country" support the peace policies of the Soviet leadership. ${ }^{40}$

National consensus and the image of an active, united youth were vital to Soviet propaganda. On the international stage, the Soviet Union proved expert at

${ }^{37}$ The source base used to understand the perspectives of the Americans and Soviets differs. I have managed to interview and correspond with a few of the American participants. I have not been able to interview any Soviet participants. Moreover, the reports produced by each side differ. The American report is full of personal reflections - about the conference, the participants themselves, the Soviet Union, and the United States. The Soviet reports on the conference, by contrast, are much less personal and are written from the perspective of the KMO as an organization.

${ }^{38}$ Gleb Tsipursky has also stressed the "fun" offered to Soviet young people through participation in various state-sponsored youth groups and activities. A key task of these groups was to inculcate a spirit of patriotism. For many Soviet youth, their patriotism was indeed heartfelt. Socialist Fun: Youth, Consumption, and State-Sponsored Popular Culture in the Soviet Union, 1945-1970s, (Pittsburgh: University of Pittsburgh Press, 2016).

${ }^{39}$ Alexei Yurchak, Everything Was Forever Until It Was No More. Gleb Tsipursky has noted that post-Thaw, the Komsomol placed great emphasis on discipline and in turn "devalue[d] grass roots voluntarism" and initiative among the country's youth. Socialist Fun, 210.

40 "Main Presentation of the Soviet Delegation," RGASPI f. M-3, op. 9, d. 1522, 11. 40-7. For the Soviet reports at the 1973 conference which can be read in similar ways, see RGASPI f. M-3, op. 8, d. 575, 11. 98-157. 
manufacturling national consensus and an image of a perfect Soviet youth in large part by excluding those most likely to rebel: dissidents, minorities, actual young people - and the kinds of people included in the American delegation. Here at this conference they set up an almost Potemkin village-like depiction of their nation's youth because through a great deal of social vetting only senior Komsomol members represented the country. Therefore this article suggests the Soviet cultural show (kult'pokaz) presented to visitors included more than visits to carefully selected model sites (prisons, schools, factories) meant to convince foreigners of the superiority of the USSR. It also included acquaintance with carefully selected people who served as the grateful beneficiaries of Soviet progress and performed the role of happy, harmonious citizens. ${ }^{41}$

\section{The American Delegation}

If the Soviet delegation at the 1972 conference appeared to march in lockstep, the American side looked divided. This divergence would be repeated at most of the future get-togethers. A Soviet report about the second Youth Conference in 1973 found the fragmented nature of the American side interesting and noted "during the discussion disputes arose not between the American and Soviet sides, but within the American delegation." ${ }^{42}$ At the same conference in Chicago, even the American bus driver and the tour leader, an American Communist named Jack Kling, fought openly with each other before their Soviet guests about how to present the United States to their Soviet guests during a guided tour of the city. ${ }^{43}$ Another official described the make-up of the 1972 American delegation as diverse and pluralistic, features many of the Americans took pride in and something "persistently stressed" and "constantly emphasized" in the discussions and their individual speeches. ${ }^{44}$ This diversity did not breed harmony, however. Several of the American participants threatened to leave the 1972 conference early because of the "sharp conflicts" plaguing the group. "These disagreements should have

${ }^{41}$ In the 1920s and 1930s, InTourist, VOKs and other Soviet agencies working with foreigners brought visitors to model sites that to present the country as if it was on the brink of the creation of a new kind of civilization. Visits to these sites were at the heart of the Soviet cultural show which sought to convince both visitors and Soviet citizens of the superiority of the USSR. Critics of those visitors who praised the Soviet Union at this time accused them of being fooled by a new kind of Soviet Potemkin village. On Potemkin villages and model sites, see Michael David-Fox, Showcasing the Great Experiment: Cultural Diplomacy and Western Visitors to the Soviet Union, 1921-1941 (New York: Oxford University Press, 2011), 98-107.

42 "Report about work with Group 5," RGASPI f. M-3, op. 8, d. 575, 11. 77-8.

${ }^{43}$ Jack Kling, the tour leader, wanted to show the seedy side of Chicago. The bus driver, Bob Prange, said Kling was "feeding them a line - the Communist line. That's not what this city's about. Let them see everything. Let them see the good, the bad, and the middle." Soviet report on press coverage of the 1973 conference, including clippings from the Chicago SunTimes and the Chicago Tribune, RGASPI, f. M-3, op. 8, d. 575, 1. 210-2, 217, 218.

44 "Report about the meeting of Soviet and American Youth," RGASPI f. M-3, op. 8, d. $299,11.112-124$.

45 "Report about the meeting of Soviet and American Youth," RGASPI f. M-3, op. 8, d. $299,11.112-124$ 
been settled before we left" because the disputes ended up harming the effectiveness of the conference and reflected poorly on the American side, recalled one American participant. ${ }^{46}$

The content and tone of the American presentations also differed sharply. While Soviet presentations championed Soviet successes and national consensus, the Americans dwelled on their country's failures and fractures. If the Soviet delegation's presentations can be described as performances of patriotism and unity, the American side offered up highly-individualistic performances of oppression. One speaker, Richard Simmons of the Young Workers Liberation League (YWLL, the youth wing of the American Communist Party), told the assembled audience that "We, American youth, live in a period of extreme turmoil characterized by the militarization of our economy, which has affected our youth environment with the disease of death due to war, and living death due to drugs and joblessness." ${ }^{47}$

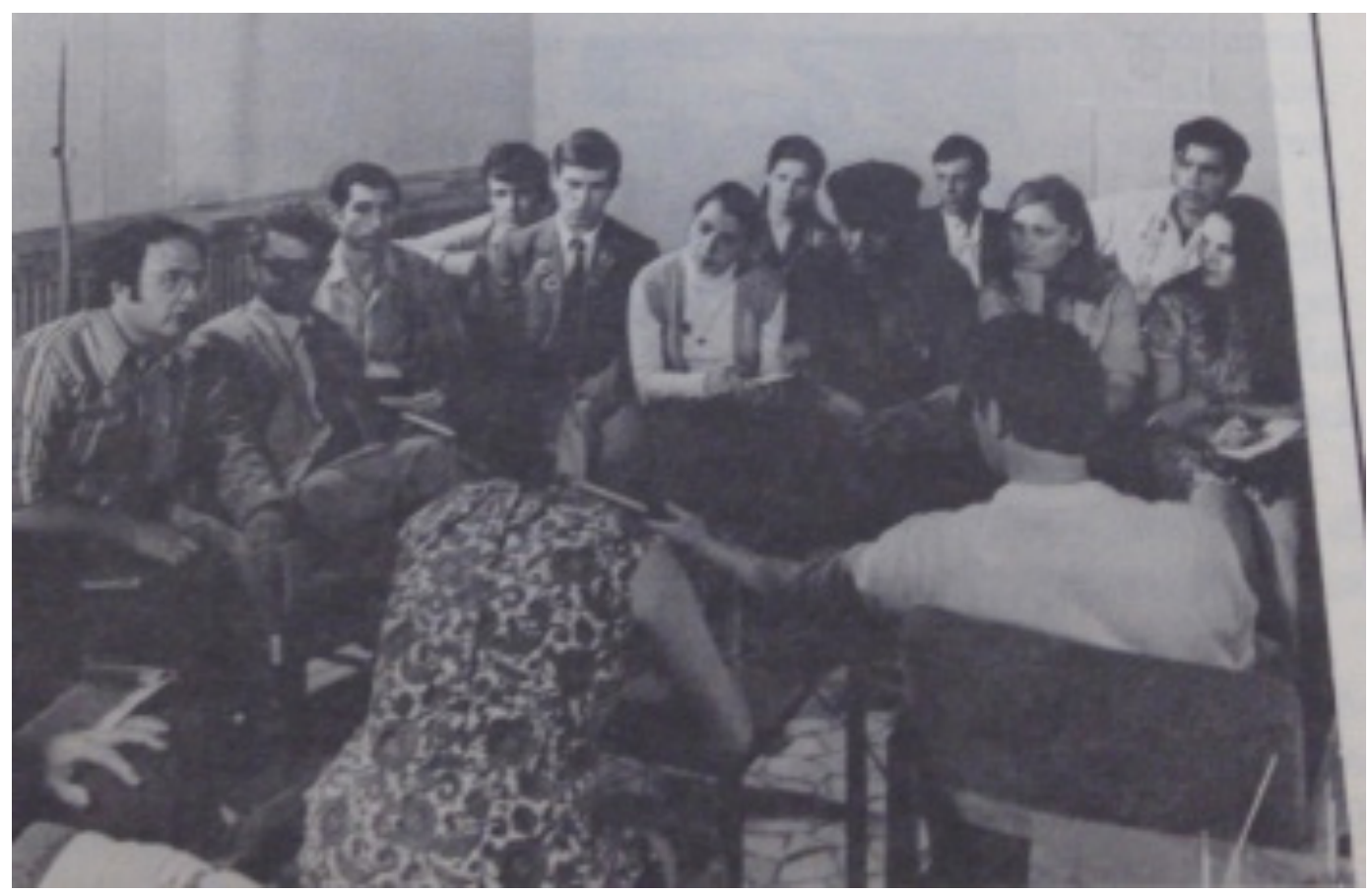

Small group discussion at the 1972 Conference in Minsk, TAM 134, Box 7, Folder 92.

Many of the other presentations followed the pattern laid by Simmons. Several speakers from the American side ragged on their country, focusing on the poverty, racism, and violence present in the United States. Chicano, Puerto Rican, and Native American activists all advocated either separatism or national independence for their communities to prevent further "genocide" by the American government. ${ }^{48}$ Indeed, a KMO report happily noted the communists within

${ }^{46}$ See the comment from Ed Rivera, RGASPI f. M-3, op. 8, d. 299, 11. 57-64.

47 "US-USSR Youth Conference," 61.

${ }^{48}$ See the published excerpts from the speeches by Evelyn Aracon (Chicano), John Beaudin (Native American), Gabriel Ramos (Puerto Rican), in "US-USSR Youth 
the American delegation took advantage of the "open tribune" and savored their opportunity to propagandize their views before their fellow Americans. ${ }^{49}$ Rick Roberts, one of the American participants, said sarcastically he learned a great deal at the conference, most especially from the leftist members of the American delegation and their specific calls to nationalize certain sectors of the American economy. Other members worried the American delegation's strong left-wing bent gave the Soviet side the wrong impression. "I would like to warn the Soviet delegation that the American delegation does not represent the United States," wrote Jim Boldt in his post-conference comments to the Soviet organizers. ${ }^{50}$

The noticeable divide between the patriotic, optimistic Soviets on one side and the cynical Americans disappointed in their country on the other stunned many of the American attendees. Some of the Americans left the USSR impressed by the organized and confident demeanor of their Soviet counterparts. Their comradery and unity were "so different. [A] Non-American reality," commented one American participant. ${ }^{51}$ The Soviet side's shared sense of purpose, their optimism, altruism, and their belief that they had a constructive role to play in their society and the realization they lacked all these things struck the American participants. "Not only did I learn about the USSR, I learned about the States and about myself as well," commented one American. ${ }^{52}$ The Soviet side noticed this difference, too. As recalled by one of the Americans, a Soviet interpreter commented that the Americans appeared to lack "any collective or community spirit." "We all seemed to look out only for ourselves," confirmed Janet Crane, a student from the University of Wisconsin. "By the same token, I definitely did perceive this type of fellow feeling among the Soviets. And again I think it is a reflection of our societies." 53 When some of the Americans strived to find common ground on the theme of alienation and disappointment, they pressed their Soviet colleagues to identify problems in their country. The Soviet side resisted. Their concerns, namely "agricultural backwardness," drunkenness, and the lack of day care centers, might have appeared too innocuous for some of the Americans to relate to. ${ }^{54}$ One "disillusioned" delegate later grumbled to the American press that the Soviets "just said the same thing over and over. When we asked about a particular problem, they would say, 'We don't have that problem in the Soviet Union.." 55

Refusal to acknowledge Soviet faults or offer any dissent from the party line continued at the later youth forums and was a feature of Soviet delegations at other international conferences, meetings, and seminars. This frustrated the typically frank and self-critical Americans. At the 1973 Youth Conference, for instance, the

Conference," 65-6, 68-9, 70-1. Racial minorities, as per the wishes of the KMO and the NCASF made up a significant portion of the American delegation.

${ }^{49}$ RGASPI f. M-3, op. 8, d. 299, 11. 112-124.

${ }^{50}$ Comments from American participants, RGASPI M-3, op. 8, d. 299, 11. 57-64.

${ }^{51}$ Anonymous comment in "US-USSR Youth Conference," 74.

${ }^{52}$ Anonymous comment in "US-USSR Youth Conference," 75.

${ }^{53}$ Comment from Janet Crane, "US-USSR Youth Conference," 52.

${ }^{54}$ Comment from Janet Crane, "US-USSR Youth Conference," 51

55 Murray Seeger, "Subjected to Propaganda: Young American's Illusions Shattered by Visit to Russia," Los Angeles Times, July 9, 1972. 
Soviet delegation refused to answer questions about the status of Soviet Jews. ${ }^{56}$ Other Americans participating in Soviet conferences encountered similar resistance to straying from the Party line. One American woman visiting the USSR in 1966, as part of a delegation of Quakers to participate in a two-week seminar on international issues, found "no dissenting voice to any fundamental government policy" among her Soviet colleagues. During the seminar, "when a party policy on the war in Vietnam or the Cuban missle [sic] crisis, for instance, was expressed, we would ask, 'And does no one feel differently about this issue in any way?' and feel like shaking the USSR participant from his unshakable statement that among 200 million people there was no one who disagreed with expressed policy." ${ }^{57}$

\section{The Rejection of Consensus}

The American delegation at the 1972 Youth Conference, which strikingly featured many of those previously written out of the American Cold War national narrative (students, radicals, and people of color), reflected the illusory nature of America's national consensus and how it had been smashed by formerly excluded groups now determined to make their voices heard. Historians now speak of the American Cold War consensus as an "illusion of unity." To manufacture a homogenous national identity and a narrative of anti-communism, whole groups of Americans needed to be excluded. ${ }^{58}$ This image of consensus in the United States began to shatter in the face of the civil rights marches, anti-war protests, assassinations, and the student demonstrations that marked the 1960s and 1970s.

For American youth, especially those more-radically minded like many of those who made up the American delegation, national consensus was no longer a virtue, especially if it required the silencing of others. The NCASF, which organized the 1972 American delegation, likewise had been one of the rare voices objecting to America's bipartisan anti-communist, anti-Soviet national mission since the late-1940s. ${ }^{59}$ Besides the American Communist Party, the NCASF was the

${ }^{56}$ Clipping from the American newspaper, Jewish Journal, RGASPI, M-3, op. 8. d. 691, 1. 224.

${ }^{57}$ Field Report-Trip to the Soviet Union, December 1966, Betty Little, Member of American Friends Service Committee Delegation, Barbara Stuhler Papers-151. K. 16. 12F. Box 14, Minnesota History Center.

${ }^{58}$ Alan Brinkley, "The Illusion of Unity in Cold War Culture," in Rethinking Cold War Culture, ed. Peter J. Kuznick and James Gilbert (Washington, DC: Smithsonian Books, 2001), 62, 72, and Peter Filene, "Cold War Culture Doesn't Say It All," in Ibid, 157; Tom Engelhardt, The End of Victory Culture: Cold War America and the Disillusioning of a Generation, (New York: Basic Books, 1995); See also the discussion of this issue in Clare Croft, "Ballet Nations: The New York City's Ballet 1962 US State Department-Sponsored Tour of the Soviet Union," Theatre Journal 61:3 (October 2009), 438-9, 441.

59 The NCASF opposed the Marshall Plan, the creation of NATO, and the Truman Doctrine, while its membership actively supported Henry Wallace's 1948 presidential campaign on the Progressive Party ticket, see, David B. Wagner, "Alone Together: American Intellectuals in the American Soviet Friendship Movement," (PhD Diss., University of California Riverside, 2016), 588. On other aspects of the group's work, see Julia Tatiana Bailey, "The National Council of American-Soviet Friendship and Art in the Shadow of the Cold War," Archives of American Art Journal 56:1, 2017, 42-65. 
most pro-Soviet organization in the country and therefore drew upon its members and those from other radical or progressive groups to form the American delegation. Several members of the American delegation selected by the San Francisco chapter of the Friendship Society were the children of American Communists or other Soviet sympathizers. ${ }^{60}$ The conference also served as an opportunity for the NCASF and the Soviet Union to attract a more youthful contingent to the cause of Soviet-American friendship. Soviet officials in the past had been consistently critical of the Soviet-American friendship groups for having a mostly geriatric base of supporters. ${ }^{61}$ Following the conference, a few of the American participants planned to jump start the NCASF's youth wing and promote the USSR to American youth. ${ }^{62}$

Witnessing the display of unity on the Soviet side and the collective pride in their country and faith in their government, meanwhile, perplexed some of the American attendees. For the Americans, such beliefs had been shaken by the Vietnam War. Unlike the Soviet side whose mission in life appeared fused with the goals of the state, the Americans, with many coming from college campuses roiled by anti-war protests and student demonstrations and some being members of radical groups, had grown increasingly alienated from their home country and disillusioned with traditional politics. The Soviet side, almost all of whom were members of an official, state-sponsored youth group, could not grasp the alienation, lack of identity or the "continuing philosophical search for meaning" faced by many of the Americans, remembered one American delegate. ${ }^{63}$ The Soviets were unprepared for the multiplicity of problems faced by the young Americans, confirmed the leader of the American delegation. ${ }^{64}$

At the conference, we can see how the American Cold War narrative with its united front and homogenous national identity had disintegrated. Yet, the Soviet Union's own Cold War narrative and united front appeared to hold strong - at least on the surface and especially when the USSR could be represented by senior Komsomolites. For some of the American delegates, however, the outward posture of the Soviet youth appeared too good to be true. And the Soviet emphasis on staging a show of consensus might have backfired at the conference.

${ }^{60}$ Gosudarstvennyi arkhiv Rossiiskoi Federatsii (GARF), f. 9576, op. 9, d. 105, 1. 87.

${ }^{61}$ One Soviet report on the NCASF suggested the group operated in a "narrow circle" consisting mostly of pensioners of primarily Russian and Jewish descent. Spravka on the NCASF by Tamara Mamedova, 1963, GARF f. 9576, op. 18, d. 233, 11. 254-7. Prominent Soviet visitors to the US frequently met with the local friendship societies. Many were critical about the absence of young members, see the report G. L. Bondarshevskii, October 1980, GARF f. 9576, op. 20, d. 2764, 11. 43-54.

${ }^{62}$ Record of Conversation with Victoria Stevens, signed by Iu. Goriachev, September 4, 1972, GARF, f. 9576, op. 9, d. 85, 11. 148-151; Report about visits to San Francisco, Los Angeles and Seattle, August 18, 1972, GARF f. 9576, op. 9, d. 85, 11. 139-141.

${ }^{63}$ Comment from Janet Crane, "US-USSR Youth Conference," 13.

${ }^{64}$ Comment from Earl Scott, NCASF Minutes/Board Notes from 1972, TAM 134, Box 1, folder 52 . 
During the Cold War, while each side sought consensus, the accusations of enforced uniformity also became a weapon in the Cold War battle of images. The conception of the Soviet people as a monolithic bloc devoid of individuality in favor of conformity took hold in the American Cold War political imagination. This conception, often accompanied by adjectives like gray and cold to describe Soviet society, was used to critique and draw attention to the paucity of consumer goods and individual freedom in the Soviet Union. During the early Cold War, Soviet youth, in particular, were often imagined as "unthinking, conforming robot[s]." 65 The sameness of Soviet dress, the uniform appearance of Soviet housing blocs, and the aggressively pro-Soviet posture of the types of people, such as InTourist guides and other tourism workers, they encountered only served to accentuate this imagined picture of an ugly Soviet homogeneity for the foreigners who passed through the country. ${ }^{66}$ Much like those short-term tourists who left the Soviet Union with the mistaken impression that the country marched in unison, some in the American delegation came away with a similar impression because their knowledge of the Soviet public and the country had been primarily shaped by members of the Komsomol.

At the 1972 Youth Conference, some of the American delegates rendered the appearance of consensus among Soviet youth a fault. One American remarked, "I felt young Soviets believe, very sincerely, that they are engaged in a great noble, social, political, economic experiment with the best form of government possible. The attitudes of the young people toward themselves as individuals was difficult for me, as an American, to believe. It seemed unreal." While another concluded that although it might be a "cliché" to declare that the USSR's youth "are pretty much alike in all but subtle ways," this American found it to be true. "But I saw that not only do they all believe many of the same things, but that it must be like that in order for the system to maintain itself," they concluded ${ }^{67}$ The drive for consensus had seemingly stolen their individuality and their apparent devotion to the state clashed with the anti-establishment mood of the Americans. Others questioned whether such consensus and uniformity were positive virtues. "I was surprised and worried by the lack of contradictions among people," Jim Boldt told the KMO. "What is it for?" 68 Another flatly and negatively stated, "young people [here] have no contradictions." 69

${ }^{65}$ As Margaret Peacock has argued, Soviet authorities at the 1957 Moscow World Youth Festival actively sought to redraw this image of Soviet youth by replacing "uniformity, constancy and reliability as the idealized traits" with "artistic expression, creativity, and individualism." Peacock, "The Perils of Building Cold War Consensus at the 1957 Moscow World Festival of Youth and Students," Cold War History 12:2, 2012, 525.

${ }^{66}$ However, Americans who managed to stay in the Soviet Union for longer periods frequently rejected such notions. Making friends with a variety of Soviet people, some American visitors found Soviet citizens to be as individualistic and diverse as any. For example, Sally Belfrage, A Room in Moscow (New York: Reynal \& Company, 1958), 182.

${ }^{67}$ The preceding quotations are all anonymous, "US-USSR Youth Conference," 73-75.

${ }^{68}$ RGASPI f. M-3, op. 8, d. 575, 11. 57-64.

${ }^{69}$ Anonymous comment, "US-USSR Youth Conference," 73. 


\section{Breakdown of Solidarity}

Reading between the lines of the American commentary on the conference one gets the sense that some on the American side considered their Soviet counterparts insufficiently radical. The performative aspects of the conference such as the carefully scripted presentations may have come off as staid to these more militant Americans accustomed to the heated debates back home on their college campuses where challenging authority stood as a virtue. While the words of the Komsomolites in opposition to war and imperialism matched the script of any progressive, the consensus on display on the Soviet side may have also smacked of conformity. One Soviet delegate even told one of the Americans, "The interests of the individual must mesh with those of society." 70 Rather than challenge authority, the Soviet youth demonstrated incredible deference to their country's leadership. In the largely sympathetic American report of the conference, the American attendees spoke of the Soviet delegation as a single mass seemingly lacking any internal diversity. ${ }^{71}$ No names or individual characteristics of any of the Soviet delegates could be recalled and few personal interactions remembered. Even two of the three Soviet speeches included in the American report, later published as a pamphlet, lacked the name of the presenter.

Others were more upfront about their disappointment in the Soviet Union's failure to live up to their radical standards. Alan Bernstein chastised the Soviet Union for abandoning proletarian internationalism in favor of peaceful co-existence and argued the Soviet Union no longer adhered to "true MarxismLeninism." "72 This was a common sentiment shared by many radicals, especially radical youth in the late 1960s and 1970s. For them, the Soviet Union was no longer synonymous with radicalism and in their search for inspiration their attention turned towards other seemingly more radical (and non-European) societiesCuba, China, North Vietnam. ${ }^{73}$

Another critic, Michael Cutting, found the Soviet Union out of step on the issue of race. He and others rejected the Soviet insistence on prioritizing class over race. "They kept telling us everything in the world is a class problem, but I know it is more of a color problem." He continued: "they wanted us to organize the blacks, the Chicanos, the youth and the women in to a single class organization." "74 The Soviet organizers then failed to appreciate the importance of race to the American participants and the flowering of the ethnic pride movement

\footnotetext{
70 "US-USSR Youth Conference," 46.
}

${ }^{71}$ The report was published as a stand-alone pamphlet titled, "The First-Ever USAUSSR Youth Conference-Minsk, Byleorussia, 1972," and can be found in TAM 134, Box 7, Folder 92. The pamphlet was reprinted as "US-USSR Youth Conference, Minsk, 1972", New World Review, Winter 1973, 41-77 and this version has been cited throughout the paper.

${ }^{72}$ Bernstein made these comments to KMO, RGASPI f. M-3, op. 8, d. 575, 11. 57-64.

${ }^{73}$ Robert Gildea, James Mark, and Niek Pas, "European Radicals and the "Third World:' Imagined Solidarities and Radical Networks, 1958-73," Cultural and Social History, 8:4, 450.

${ }^{74}$ Murray Seeger, "Subjected to Propaganda: Young American's Illusions Shattered by Visit to Russia," Los Angeles Times, July 9, 1972. 
in the US. Moreover, the Soviet organizers failed to understand these Americans were representatives of the New Left, not the Old Left who closely identified with the USSR in the 1920s and 1930s and whose focal point was class. ${ }^{75}$ The American side, which included many racial minorities, had requested that a significant portion of the Soviet delegation be composed of (Uzbeks, Tajiks, Kazakhs, etc.) people who they considered to be the Soviet Union's own racial minorities and people who they could find common ground. This wish was not granted, however.

The Soviet attempt to formalize proceedings, replete with official ceremonies, led to other unexpected occurrences and reversals. Such ceremonies and the efforts to treat the diverse set of individuals who made up the American delegation as a single national delegation, according to one Soviet report, inadvertently revived feelings of patriotism among some of the typically left-wing American attendees. This made them feel responsible for their behavior as citizens of a "great country," even though the Americans initially believed they represented only themselves. According to the same report, this caused some of the Americans to adopt a patriotic position, defending their country under a barrage of criticism-America was genocidal and cannibalistic according to some of the speeches, while no one appeared to utter anything resembling criticism of the Soviet Union-and questioning the Soviet Union even though such stances conflicted with their beliefs. ${ }^{76}$ Even Charles White, a self-described Maoist from Howard University who wore a Mao button to the conference (which organizers forced him to remove), said he never felt more American or conservative than at the conference. "In the United States, I am considered left of the left. Here, I felt as if I were to the right of George Wallace." $"$ So, while the posture of unity present among the Soviet delegation led some of the American attendees to grow more conscious of their alienation, the constant attacks on their country brought some of feuding Americans back together again.

The Soviet side expected the American delegation to be made up of progressive youth, who, like Simmons, would express opposition to their government. One lengthy Soviet report of the 1972 conference acknowledged the American side did not field a delegation representative of American youth in general. ${ }^{78}$ This

${ }^{75}$ The Soviet insistence on prioritizing class over race stirred dissension among a previous generation of African American visitors to the Soviet Union, see Meredith L. Roman, Opposing Jim Crow: African Americans and the Soviet Indictment of U.S. Racism, 1928-1937 (Lincoln: University of Nebraska Press, 2012).

76 "Report about the meeting of Soviet and American Youth," RGASPI, M-3, op. 8, d. 299, 11. 112-124.

77 "U.S Maoist Youth Finds Soviet a Doctrinaire Place," New York Times, July 11, 1972.

78 "Report about the meeting of Soviet and American Youth," RGASPI, M-3, op. 8, d. 299, 11. 112-124. The New Left fascinated and perplexed Soviet officials and they repeatedly misjudged them. Most New Left adherents sought a fresh break from the past and a new form of participatory democracy. Few New Leftists were pro-Soviet and many condemned the US and the USSR in equal measure. The New Leftists from various countries caused problems at other Soviet sponsored conferences and festivals, Pia Koivunen, "Overcoming 
clashed with the original goal, promoted in a series of press releases and official statements, of sending a diverse group to see the Soviet Union for themselves and represent the United States. Yet, the initial talk of representativeness seemed to be mostly just lip-service. And the KMO did not seem to mind this discrepancy and even desired it. Indeed, in the opening statement of the conference, a Soviet representative characterized the American guests as purely progressive young people who "mov[ed] in the vanguard of the anti-war movement" and were battling the scourges of racism and social inequality. ${ }^{79}$ For young people to be anything other than progressive seemed unimaginable for the KMO and the Soviet participants. ${ }^{80}$

For many of the Soviet-sponsored international conferences and seminars, the KMO and other Soviet organizations used already established relationships with non-state organizations, in this case with the NCASF a left-wing, deeply pro-Soviet group, to procure foreign audiences and delegations favorable to the Soviet Union. For this conference, Soviet officials actively involved themselves in the formation of the American delegation. For the Minsk conference, Soviet officials advocated spots for Young Workers Liberation League (YWLL) members (15 total) and other communists. ${ }^{81}$ A few Maoists however appeared to sneak through the vetting process. This delegation proved favorable to the Soviet Union with some of the other American delegates joking that the YWLL members acted as delegates for the "other side." 82 In the end, they "helped create a benevolent atmosphere" and their presence neutralized the "right-wingers and Maoists" otherwise present on the American side according to the KMO ${ }^{83}$ The YWLL, a small fringe group and the youth wing of the American Communist Party, had been a favored ally and previously given the opportunity by the KMO to serve as the face

Cold War Boundaries at the World Youth Festivals," in Reassessing Cold War Europe, ed., Sari Autio and Katalin Miklóssy (London: Routledge, 2011), 182-3.

79 "Presentation before participants," RGASPI f. M-3, op. 8, d. 299, 11. 20-8.

${ }^{80}$ Despite the left-wing orientation of the delegation, one participant, Lucious Thomas from Chicago, still complained that the American delegation included the "most dishonorable, racist, pro-imperialist rightists, the worst I've ever seen in my life." RGASPI f. M-3, op. 8, d. 299, 11. 57-64.

${ }^{81}$ The NCASF and KMO gave a certain number of slots to the YWLL. Morford letter to Kavatardaze, May 24, 1972 RGASPI, M-3, op. 8, d. 435, 11. 159-60. Per negotiations between Jarvis Tyner, the head of the YWLL and a high-ranking CPUSA official, Richard Morford of the NCASF and a Soviet official, the American delegation would include 15 people from the YWLL. Tyner appeared to want Victoria Stevens, a YWLL member, to be the leader of the American delegation. Morford disagreed because he believed the other members would resent the influence of the YWLL. Earl Scott, the NCASF's youth director, instead ended up in charge of the delegation. Morford promised the conference organizers Scott would be a trusted substitute. Scott too was a Communist Party member, but importantly no one knew it. "Record of a conversation with Richard Morford," signed by Iu. Goriachev, dated June 6, 1972, GARF f. 9576, op. 9, d. 102, 1. 67.

82 "Their politics are easy to sum up: the Soviet Union is best country in the world." Lars Lih, "Account of trip to the Soviet Union."

${ }^{83}$ Report about the meeting of Soviet and American Youth, RGASPI f. M-3, op. 8, d. $575,11.112-124$. 
of American youth at other Soviet-sponsored youth events. ${ }^{84}$ Tom Abraham, an American participant, identified a key difference between the Soviet and American delegations. The Soviet side had been carefully selected and vetted. "The Soviet side is supported [by] and supports the state," he wrote. The American side, on the other hand, had been pulled together "by a small private organization" haphazardly from many sources and the result produced a messy and fractious delegation, dominated at times by the best organized and loudest contingent within it, the YWLL. ${ }^{85}$

At these future Soviet-American Youth Conferences a similar, slightly less dramatic spectacle would be repeated because Soviet officials, doggedly determined to present their youth as a united patriotic front, continued to field entire rosters made up exclusively of Party and Komsomol members - a scene of consensus only further heightened by the factious and usually radical nature of the American delegations. The 1972 conference therefore rather than provide an accurate snapshot of these two nations and their respective youth instead produced a distorted, fun-house-esque mirror version of both sides in which Soviet "youth" appeared as a monolithic bloc of devoted patriots and the American side as a rag-tag group of alienated radicals. Two unhappy American participants, speaking to the American press after the conference, castigated the event as a set-up and a farce ${ }^{86}$ For some the conference served as another Soviet propaganda stunt only this time cloaked in détente-era platitudes of open dialogue and the search for better understanding yet ultimately offering neither. Moreover, the conference failed to achieve its primary goal of fostering solidarity between American and Soviet youth. Solidarity failed to materialize in Minsk because the two sides struggled to relate to each other. The American side was too radical, alienated, and divorced from the mainstream (an inadvertent consequence of Soviet meddling in the formation of the delegation) and the Soviet side, who were often a decade older than the Americans, occupied the altogether opposite position by appearing too conformist and satisfied with their lives and country.

\section{Conclusion}

These annual Youth Conferences, which rotated between the US and the USSR, would continue through the early 1980s and several hundred young Soviets and Americans would participate in these events. ${ }^{87}$ For the USSR, the example

${ }^{84}$ For example, Questionnaires of participants at the World Meeting of Working Youth (Moscow, 1972), RGASPI f. M-3, op. 8, d. 335, 11. 104-8.

${ }^{85}$ Comments collected by KMO, RGASPI f. M-3, op. 8, d. 575, 11. 57-64.

${ }^{86}$ To combat such criticism, the NCASF organized a press conference where some of the American participants accused the critics of seeking to drive a wedge between Soviet and American youth. "US-USSR Young People's Conference: A Preliminary Report," New World Review, Summer 1972, 16-18.

${ }^{87}$ By 1983 the conference would be renamed the Forum for American-Soviet Dialogue (although it was occasionally called the Meeting of Soviet-American Youth) and professionalized with the American side now largely featuring professionals and even Soviet experts. List of American delegates and staff, RGASPI f. M-3, op. 11, d. 154c, 1l. 1, 3-7. 
of these conferences attests to the determination on the part of the KMO and the Soviet authorities to seek careful contact with young people beyond their borders and showcase the unity and consensus of Soviet youth. For the individual American participants, the continuation of these conferences demonstrated the great desire of some in the US to meet Soviet people their own age, travel past the "Iron Curtain," and the resonance of the détente-era message promoted by the conference about the potential of such people-to-people exchanges to break down barriers and reduce Cold War tensions. The conference offered them the very real possibility to participate personally in détente. ${ }^{88}$

The 1972 conference overall served as a sort of microcosm of Soviet policy toward visitors. ${ }^{89}$ Contact was sought but it had to be controlled and shaped into an agreeable form. Organizers privileged formal speeches over open-ended discussions and approached the whole situation didactically, as a way to teach ignorant foreigners about the achievements of the USSR. Soviet officials involved themselves in the formation of the American delegation to secure a group of Americans considered more favorable to the USSR and one more likely go along with the Soviet wish for transnational youth solidarity on Soviet terms. Moreover, the YWLL members and the other ultra-radicals that made up a significant portion of the American delegation offered only the familiar image of a cruel, exploitative America to a Soviet audience made up almost exclusively of Party and Komsomol members, who likewise confirmed many of the stereotypes westerners already had of Soviet youth. Therefore, this conference rather than demolish Cold War stereotypes only served to confirm them in the minds of many of its participants. All the differences between the delegations, meanwhile, existed alongside and unintentionally challenged one of the main messages of the conference and a common détente-era cliché, especially prominent in American peace circles, that “they're just like us." The 1972 Youth Conference also illustrated how foreign visitors made of the opportunity to visit the Soviet Union what they wanted. Many visitors, as occurred here, upon close examination drew their own conclusions about Soviet society while rejecting aspects of the Soviet cultural show and its self-representations.

\begin{abstract}
About the Author
Andrew Jacobs completed his doctorate in Russian history at Indiana University in 2019. His dissertation titled "Contact and Control: Americans Visit the Soviet Union, 1956-1985" explores the experiences of American visitors to the USSR during the Cold War and the ways in which their Soviet hosts both welcomed them and sought to manage their Soviet experience.
\end{abstract}

${ }^{88}$ The desire for a peaceful conclusion to the Cold War became the primary rallying cry for the American participants in the conferences by the mid-1970s, see The AmericanSoviet Youth Forum's brochures and statement of purpose, TAM 134, Box 9, Folder 27.

${ }^{89}$ For an overview of the experiences of some American visitors to the post-Stalin USSR, see Andrew Jacobs, "Contact and Control: Americans Visit the Soviet Union, 19561985,” PhD. Diss., Indiana University, 2019. 